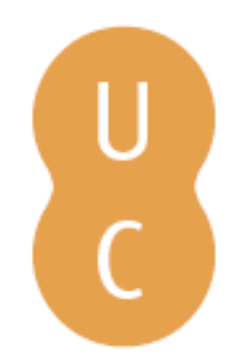

\title{
pommalina
}

\section{Self-efficacy, physical competence and self-esteem in athletes with and without disability}
Autor(es):
Ferreira, José P.; Gaspar, Pedro
Publicado por: Imprensa da Universidade de Coimbra
URL
persistente:
URI:http://hdl.handle.net/10316.2/32242
DOI:
DOI:http://dx.doi.org/10.14195/978-989-26-0474-9_6
Accessed : $\quad$ 26-Apr-2023 11:40:32

A navegação consulta e descarregamento dos títulos inseridos nas Bibliotecas Digitais UC Digitalis, UC Pombalina e UC Impactum, pressupõem a aceitação plena e sem reservas dos Termos e Condições de Uso destas Bibliotecas Digitais, disponíveis em https://digitalis.uc.pt/pt-pt/termos.

Conforme exposto nos referidos Termos e Condições de Uso, o descarregamento de títulos de acesso restrito requer uma licença válida de autorização devendo o utilizador aceder ao(s) documento(s) a partir de um endereço de IP da instituição detentora da supramencionada licença.

Ao utilizador é apenas permitido o descarregamento para uso pessoal, pelo que o emprego do(s) título(s) descarregado(s) para outro fim, designadamente comercial, carece de autorização do respetivo autor ou editor da obra.

Na medida em que todas as obras da UC Digitalis se encontram protegidas pelo Código do Direito de Autor e Direitos Conexos e demais legislação aplicável, toda a cópia, parcial ou total, deste documento, nos casos em que é legalmente admitida, deverá conter ou fazer-se acompanhar por este aviso. 
Carlos Eduardo Gonçalves

Sean P. Cumming

Manuel J. Coelho e Silva

Robert M. Malina

(Editors)

\section{Sport \\ and Education}

Oribute to OMaxtin Lee

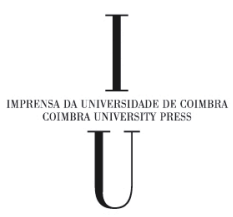


José P. Ferreira, Pedro Gaspar

University of Coimbra, Portugal

\section{SELF-EFFICACY, PHYSICAL COMPETENCE AND SELF-ESTEEM IN ATHLETES WITH AND WITHOUT DISABILITY}

\section{Introduction}

The concept of self-efficacy was introduced by Bandura (1977) to explain the effects of self-referent thoughts on psychological functioning and refers to the way people judge their capabilities to organize and execute the courses of action required to attain designated types of performance.

Self-efficacy beliefs are said to influence not only the courses of action pursued but also the effort expended, endurance when facing difficulties, the nature of thought patterns and affective reactions (Bandura, 1977). Perceived Self Efficacy is defined as a judgement of individual's potential ability to carry out a certain task, rather than an effective measure of whether or not that individual can or does perform that specific task.

In exercise and sport contexts, the Exercise and Self-Esteem Model (Sonstroem \& Morgan, 1989) is used as a self-system to explain how the effects of physical training generalise to Global Self-Esteem (Sonstroem, 1997). This model is based on dimensions of Perceived Physical Competence and Self-Acceptance that are referenced in the literature as the foundations involved in the establishment of a favourable self-esteem (Harter, 1985).

The hierarchical and multidimensional organization of the self in the physical domain suggested by Fox and Corbin (1989) when developing the Physical Self-Perception Profile (PSPP) offered the opportunity to replace the unidimensional perceived Physical Competence level of the EXSEM model with a multidimensional physical self-concept profile providing an example of how improved instrumentation in combination can offer a more comprehensive and systematic framework for the study of self-perceptions through exercise (Fox, 2000). The baseline of the model consists of objective evaluations of physical performance that might be enhanced through training. A Self-Efficacy statement based on objective measures of physical performance such as game statistics represents the first self-perception variable and provides the bridge from the physical to representations of the physical within the mind of the person (Sonstroem, 1997). 
Within this model Self-Efficacies are believed to be closely related to perceived physical competence as well as to present moderate to large associations with Global Self-Esteem (Fox, Corbin \& Couldry, 1985). This relationship found in the review of the literature among sport and exercise participants are not deeply analysed in athletes with physical disabilities. Recently Ferreira and Meek (2001), Ferreira and Fox (2004, 2005) and Ferreira (2006) used a standardized instrument - the Portuguese version of the PSPP - to assess physical self-perceptions is wheelchair sport participants but no associations with self-efficacy or performance were studied.

The purpose of this study is to describe and analyse the hypothesised hierarchical relationship between perceived self-efficacy, perceived physical competence and global self-esteem variables both in basketball athletes with and without disability. The second purpose of the study is to analyse hypothetical differences in perceives self-efficacy, perceived physical competence and global self-esteem between athletes with and without disability.

\section{Methods}

\section{Participants}

Participants were 139 male basketball athletes, 59 with disability $(32.80 \pm 11.64$ yrs $)$ and 80 without disability $(21.48 \pm 4.69 \mathrm{yrs})$. All participants were competing at different levels of the National Competition (professional league, $1^{\text {st }}$ division and $2^{\text {nd }}$ division).

\section{Instrumentation}

Participants received a test battery containing a Portuguese version of the Physical Self-Perception Profile - PSPP (Fox \& Corbin, 1989), a Portuguese version of the Rosenberg Self-Esteem Scale - RSES (Rosenberg, 1965) and an adaptation of the Self-Efficacy for Walking Scale (Sonstroem et al., 1991). The PSPP consists of five sub-scales with six items displayed in a structured alternative format with a possible range of scores from 6 to 24 . Subjects are presented with two contrasting descriptions of people and they are asked to select the description most like themselves and afterwards the intensity of the agreement with that description, i.e., to choose whether this description is "sort of true to me" or "really true to me". This structured alternative format was developed by Harter (1985) and has been shown to overcome socially desirable responding (Fox, 1990). Validity and reliability of the instrument for the Portuguese population has previously been analyses in a series of studies with different Portuguese groups (Fonseca \& Fox, 2002; Ferreira \& Fox, 2002a, 2002b; Ferreira \& Fox, 2004).

The Rosenberg Self-Esteem Scale (RSES) is a uni-dimensional ten-item instrument using a four-point Likert Scale to which participants respond from strongly agree to strongly disagree. Global Self-Esteem is represented by the sum of all item scores providing a possible range of 10 to 40 with higher scores indicating higher self-esteem (GSE). RSES has been validated in different studies. Silber and Tippett (1965) reported 
a test-retest reliability value of .85. Recently Batista (1995) and Ferreira and Fox (2003) using this instrument in the Portuguese youth population reported a test-retest reliability coefficient of $\mathrm{r}=.74$. and $\mathrm{r}=.72$ respectively.

Perceived Self-Efficacy was assessed using an adaptation of the Self-Efficacy for Walking Scale (Sonstroem et al., 1991). Participants expressed in percentage values from 0 to $100 \%$ their individual degree of confidence about their perceived ability to perform offensive and defensive actions in the game in each statistical item used to calculate MVP (most valuable player) score. The percentage value for perceived self-efficacy was calculated based on the average obtained for all items analysed.

\section{Procedures}

Participants were tested in small groups ranging from 5 to 12 individuals after training sessions, with previous consent from coaches and from the National Organisation. Test batteries were administrated by the same research assistant after a short briefing about the purpose of the study. Standardized instructions were used and for athletes with language difficulties questions were read to them. Standardised instructions were given to all participants as well as encouragement to ask for help.

\section{Data analysis}

All statistical analyses were performed using SPSS for Windows - version 13.0 with an alpha 5\% significance value. Persons product correlation analysis (Persons r) was used to describe relationship between variables and multiple regression (using stepwise and enter method) was used to explain the percentage of the variance explained for each relationship. Comparisons between samples were done using independent t-tests.

\section{Results}

Descriptive mean score values from self-efficacy, physical competence (physical confidence, body attractiveness, physical strength and physical self-worth domains) and global self-esteem were analysed by status (see table 1 ).

Table 1. Mean score and standard deviation values for physical self, global self-esteem and perceived self-efficacy in basketball athletes with and without disability

\begin{tabular}{lcccccc}
\hline & \multicolumn{3}{c}{ With disability } & \multicolumn{3}{c}{ Without disability } \\
\cline { 2 - 7 } & $\mathrm{n}$ & $\mathrm{M}$ & $\mathrm{SD}$ & $\mathrm{n}$ & $\mathrm{M}$ & $\mathrm{SD}$ \\
\hline Physical Confidence & 59 & 17.24 & 4.01 & 80 & 18.03 & 2.94 \\
Body Attractiveness & 59 & 15.00 & 3.30 & 80 & 16.06 & 2.92 \\
Physical Strength & 59 & 16.37 & 3.06 & 80 & 16.08 & 2.93 \\
Physical Self-Worth & 59 & 16.59 & 3.63 & 80 & 16.91 & 2.67 \\
Global Self-Esteem & 59 & 18.46 & 4.71 & 80 & 19.28 & 4.43 \\
Self-Efficacy & 59 & 46.44 & 10.30 & 80 & 48.25 & 8.96 \\
\hline
\end{tabular}


Athletes without disability showed higher mean score values for all domains of the physical self than athletes with disability but not for physical strength. Athletes with disability reported higher levels of satisfaction with their physical strength and felt more confident in situations requiring strength than athletes without disability. Athletes without disability also presented higher mean score values for both global self-esteem and perceived self-efficacy than athletes with disability. However perceived self-efficacy scores found both in groups with and without disability are very low and below $50 \%$.

Figure 1 presents Pearson's $\mathbf{r}$ coefficients and multiple regression analysis values (in brackets) of basketball athletes without disability $(n=80)$.
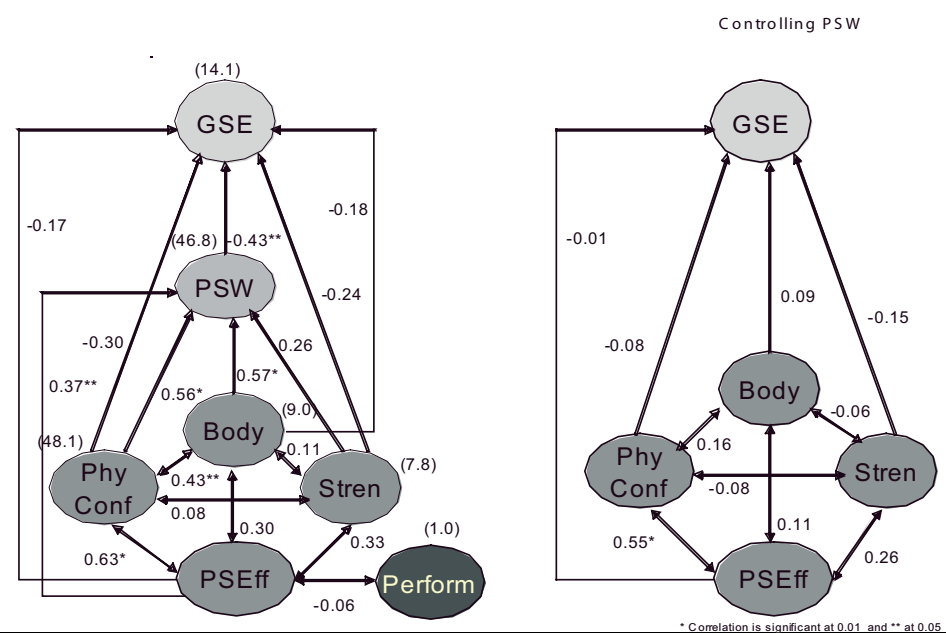

Figure 1. Standardized and expanded solution of the EXSEM model - basketball athletes without disability
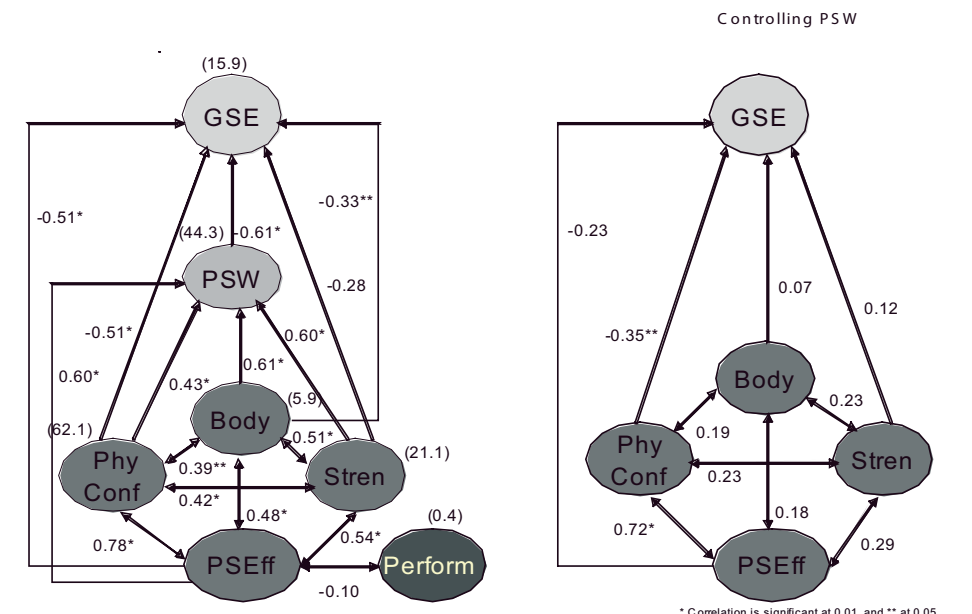

Figure 2. Standardized and expanded solution of the EXSEM model - basketball athletes with disability 
Physical self-worth showed the strongest relationship with global self-esteem of all PSPP subscales. All PSPP subscales presented stronger relationship with PSW than with global self-esteem. Relationships between the sub-domain scales and global selfesteem was greatly reduced or even extinguished when effects of PSW are statistically removed by partial correlation. Finally, relationships among sub-domain scales are weaker when the effects of PSW are statistically removed.

Negative correlations among constructs were found between self-perception subscales and perceived self-efficacy both with global self-esteem suggesting that for basketball athletes without disability physical self-perceptions and self-efficacy are perceived as not relevant to introduce significant changes on the way these athletes perceive themselves as persons.

Figure 2 presents Pearson's $\mathrm{r}$ coefficients and multiple regression analysis values (in brackets) of basketball athletes with disability $(n=59)$. The pattern of relationships found in basketball athletes with disability is similar to the one found for athletes without disability for all PSPP subscales, for perceived self-efficacy and for global self-esteem. Results also suggest a strong relationship among constructs in the baseline of the model and support its hierarchical organization and the existence of PSW as a mediating variable between specific self-perceptions and global self-esteem. Results also support the existence of a moderate to strong relationship between physical confidence and perceived self-efficacy, leading to the possibility that athletes with higher positive feelings about their ability to maintain high levels of stamina and fitness as well as an high ability to learn and perform sport skills, in different sport and exercise settings, perceive very positively their potential ability to perform certain sport and exercise tasks, whether or not they will be able to perform them correctly. However the correlation coefficient between perceived self-efficacy and performance was negative suggesting that both athletes with and without disability have a very critical opinion about their own level of performance and participation in the game.

Multiple regression analyses revealed that perceived self-efficacy was able to explain $48.1 \%$ of the variance in Physical Confidence for athletes without disability and $62.1 \%$ of variance in Physical Confidence for athletes with disability. In athletes with physical disability self-efficacy was also able to explain $21.1 \%$ of the variance in physical strength. Multiple regression results also revealed that the three sub-domain scales (physical confidence, body attractiveness and physical strength) were able to explain $46.8 \%$ of the variance in PSW for athletes without disability and $44.3 \%$ of variance for athletes with disability, providing further evidence that they adequately represent self-perception content in the physical domain for both Portuguese basketball athletes with and without disability. On the other hand, multiple regression analysis also revealed that PSW was able to explain $14.1 \%$ of the variance in GSE for athletes without disability and $15.9 \%$ of the variance in GSE for athletes with disability.

To investigate whether disability influenced perceived self-efficacy, self-perceptions in the physical domain variables as well as global self-esteem, an independent t-test was conducted using status as independent variable and perceived physical self, selfperception in the physical domains and global self-esteem as dependent variables. Results showed significant statistical differences for body between athletes with and without disability $(\mathrm{p} \leq .05)$. Athletes with disability expressed lower mean score values than their peers without disability. 
To investigate whether disability influenced performance among groups with and without disability, a independent t-test was conducted using status as independent variable and MVP value as dependent variables. Results showed significant statistical differences for MVP between male athletes with and without disability $(\mathrm{p} \leq .05)$. Athletes with disability expressed lower mean score values than their peers without disability.

\section{Discussion}

The first aim of this study was to describe the level of perceived physical competence, perceived self-efficacy and global self-esteem variables in basketball athletes with and without disability and to analyse the hypothesised hierarchical relationship between these variables in both groups. The present study revealed that perceived physical competence based on individual perceptions in the physical domain, perceived SelfEfficacy and Global Self-Esteem are much similar both in Portuguese basketball athletes with and without disability as fewer differences were found between the two groups. This study also supports the idea that physical disability can adversely impact on feelings of physical and sexual attractiveness, causing strong negative feelings towards the body as a consequence of shame, discomfort and lack of acceptance of disability as well as unhappiness and stress towards the body (Taleporos \& McGabe, 2001) as athletes with physical disability showed lower mean score values for all domains except for Physical Strength. Physical Strength was identified as an important component of physical self of basketball athletes with physical disabilities as this dimension was highly valued by this group probably because Physical Strength can be empowered through regular sport and exercise but has also very important effects in every days life, making daily routines easier to achieve and providing the opportunity for active people with physical disabilities to make the difference in attitude and will when compared with other sedentary groups with and without disability. Similar results were previously reported by Ferreira (2006) in a study with Portuguese wheelchair basketball players. Autonomy and ability to perform in different levels and contexts provides a good opportunity to reduce social stigma (Goffman, 1968), to promote individual and professional skills and to reduce disadvantage, promoting alternative ways of thinking and viewing disability in social context and providing important opportunities for both social and professional integration.

Basketball athletes with and without disability perceived low levels of Self-Efficacy suggesting that they are very critical about their own performance and perceiving individual participation in the game and team members contribution to team success as something much less positive than it appears to be in reality.

Zero-order correlation coefficients and partial correlation coefficients (figures 1 and 2) of Portuguese basketball athletes with and without disability provide evidence for the proposed hierarchical organisation with Global Self-Esteem. GSE correlated highly, however negatively, with the PSW sub-domain than all the other sub-scales. Each of the sub-domain scales showed a stronger relationship with PSW than with GSE. Partial correlation coefficients showed that the significant relationship between GSE and the three sub-domain scales is almost extinguished when the effects of PSW were statistically removed. Evidence was also found for the hypothesis that hierarchical organization among constructs would include perceived Self-Efficacy 
at the baseline of the model as suggested by Sonstroem et al. (1991) e Sonstroem, Harlow, e Josephs (1994). The hierarchical structure is therefore confirmed in these correlational analyses.

The present study provided further support for the negative correlation between physical self and Global Self-Esteem in Portuguese samples with and without (Ferreira \& Fox, 2004; Ferreira \& Fox, in press). These results do not support those found in the review of the literature for groups without disability (Atienza, Balaguer \& Moreno, 1997; Fox \& Corbin, 1989; Page, Ashford, Fox \& Biddle, 1993; Hagger, Ashford \& Stambulova, 1998) as this relationship is usually described as moderate to high (0.5 to 0.7). Perceived Self-Efficacy seemed to associate rather well with Physical Confidence and Physical Strength and not so well with Body Attractiveness, specially in the group with physical disability. Unexpectedly the relationship between Self-Efficacy and performance turned to be inconsistent and very weak.

A second aim of the study was to assess the hypothetical differences in perceived Self-Efficacy, perceived Physical Competence and Global Self-Esteem between athletes with and without disability. Body Attractiveness proved to be a sensitive issue among athletes with disability. In spite of being very active and healthier athletes with physical disabilities tend to express less positive feelings about the ability to maintain their bodies attractive and to feel confident in appearance when compared with other male basketball athletes without physical disability.

In summary, the present study documents a strong association between perceived Self-Efficacy and Physical Competence through strong feelings of physical strength for athletes with disability and through strong feelings of Physical Confidence in both athletes with and without disability, supporting the role of the physical self as a mediator to Global Self-Esteem. The results of this study may contribute to further understanding of the psychological benefits of sport participation in groups with disability.

\section{References}

Atienza F, Balaguer I, Moreno Y (1977). Factorial validity of the Physical Self-Perception Profile (PSPP) in the case of Spanish adolescents. In R. Lidor and M. Bar-Eli (Eds.) Proccedings of the IX World Congress of Sport Psychology: Linking theory and practice.1997, July, Israel, p.82-84.

Bandura A (1977). Self-efficacy Toward a unifying theory of behavioural change. Psychological Review. 84: 191-215.

Batista P (1995). Satisfação com a imagem corporal e autoestima - estudo comparativo de adolescentes envolvidas em diferentes níveis de actividade física. Master Thesis, University of Porto, not published.

Ferreira JP (2006) Physical Self and Global Self-Esteem in Wheelchair Sport Participants: A mixed method approach. Coimbra: FCDEF-UC.

Ferreira JP, Campos MJ (2007). Principais benefícios do exercício e da prática desportiva regular em grupos com necessidades especiais. Revista Horizonte. Nov-Dez, vol. XXI, n. ${ }^{\circ} 126$ (dossier).

Ferreira JP, Fox KR (submitted). Physical self-perceptions and self-esteem in basketball players with and without disability: A preliminary analysis using the Physical Self-Perception Profile. Submitted to the European Bulletin of Adapted Physical Activity.

Ferreira JP, Fox KR (2005) Physical self-perceptions and global self-esteem in wheelchair sport participants: A mixed method approach. Proceedings do $15^{\text {th }}$ International Symposium of Adapted Physical Activity - APA: a discipline, a profession, an attitude. July, Pavia \& Verona, Italy, p.123. 
Ferreira JP, Fox KR (2004) Self-perceptions and exercise in groups with special needs: Preliminary results. In J.P. Ferreira, P.M. Gaspar, C. Fontes Ribeiro, A.M. Teixeira and C. Senra (Eds.) Physical Activity and promotion of Mental Health. Faculdade de Ciências do Desporto e Educação Física - Universidade de Coimbra, Portugal, p.33-40.

Ferreira JP, Fox KR (2003). Evidence of cross-cultural validity and reliability of a Portuguese version of the Physical Self-Perception Profile. In R. Stelter (ed.) Collection of articles of the XIth European Congress of Sport Psychology - FEPSAC (CD-Rom). July, Copenhagen, Denmark.

Ferreira JP, Fox KR (2002a). Physical Self-Perceptions and Global Self-Esteem in Portuguese students. In M. Koskolou, N. Geladas \& V. Klissouras (Eds.), Proceedings of the 7th Annual Congress of the European College of Sport Sciences. July, Athens, Greece. Vol. 1, p.531.

Ferreira JP, Fox KR (2002b). Cross-Cultural Validity of a Portuguese version of Physical Self-Perception Profile. In M. Koskolou, N. Geladas \& V. Klissouras (Eds.), Proceedings of the 7th Annual Congress of the European College of Sport Sciences. July, Athens, Greece, Vol. 2, p.959.

Ferreira JP, Meek GA (2001). Portuguese wheelchair athletes self-perceptions in the physical domain: Preliminary analysis. Proceedings of the $13^{\text {th }}$ International Symposium, $5^{\text {th }}$ European Congress Adapted Physical Activity - ISAPA . July, Vienna, Áustria, p. 50.

Fonseca AM, Fox KR (2002). Como avaliar o modo como as pessoas se percebem fisicamente? Um olhar sobre a versão portuguesa do Physical Self-Perception Profile - PSPP. Revista Portuguesa de Ciências do Desporto, 2, 11-23.

Fox KR (2000). The effects of exercise on self-perceptions and self-esteem. In S.J.H. Biddle, K.R. Fox and S.H. Boutcher (Eds.), Physical activity and psychological well-being. London: Routledge, p.88-117.

Fox KR (1990). The physical Self-Perception Profile Manual. Dekalb, IL: Department of Physical Education, Office of Health Promotion, Northern Illinois University.

Fox KR, Corbin CB (1989). The Physical Self-Perception Profile: Development of preliminary validation. Journal of Exercise and Sport Psychology, 1989, 11, 408-430.

Fox KR, Corbin CB, Couldry WH (1985). Female physical estimation and attraction to physical activity. Journal of Sport Psychology, 7, 125-136.

Goffman E (1968) Stigma: Notes on the management of spoiled identity. Harmondsworth: Penguin.

Hagger M, Ashford B, Stambulova N (1998). Russian and British children's physical self-perceptions and physical activity participation. Pediatric Exercise Science, 1998, 10, 137-152.

Harter S (1985). Competence as a dimension of self-evaluation: Towards a comprehensive model of self-worth. In: R Leahy (Ed.), The Development of the Self. New York: Academic Press, p.55-121.

Page A (1993). Ashford, B. Fox, K.R., \& Biddle, S. (1993). Evidence of cross-cultural validity for the Physical Self-Perception Profile. Personality and Individual Differences, 14 (4), p. 585-590.

Rosenberg M (1965). Society and the adolescent self-image. Princeton, NJ: Princeton University Press, 1965.

Silber E, Tippett JS (1965). Self-esteem: Clinical assessment and measurement validation. Psychological Reports. 16, 1017-1071.

Sonstroem RJ (1997). The physical self-system: A mediator of exercise and self-esteem. In K.R. Fox (Ed.), The physical self: From motivation to well-being. Champaign, IL: Human Kinetics, p.3-26.

Sonstroem RJ, Harlow LL, Josephs L (1994). Exercise and Self-esteem: Validity of model expansion and exercise associations. Journal of Sport \& Exercise Psychology, 16, 29-42.

Sonstroem RJ, Harlow LL, Gemma LM, Osborne S (1991). Test of structural relationships within a proposed exercise and self-esteem model. Journal of Personality Assessment, 56, 348-364.

Sonstroem RJ, Morgan WP (1989). Exercise and self-esteem: Rationale and model. Medicine and Science in Sports and Exercise, 21, 329-337.

Taleporos G, McGabe MP (2001). The impact of physical disability on body esteem. Sexuality and Disability, 19, 293-308. 